\title{
Synthesis and Characterization of Poly O-Anisidine Nanoparticles and their Nanocomposite
}

\author{
Azza M.Mazrouaa*, M.Yahia Abed, N.A. Mansour and M.G.Mohamed
}

Egyptian Petroleum Research Institute, Petrochemical Department, Polymer Lab, Nasr City, Cairo, Egypt

\begin{abstract}
In this work, Poly o-anisidine nanoparticles was prepared by using cationic surfactant. Poly o-anisidine nanoparticles/ nanocomposites filled with constant content $1.0 \mathrm{wt} \%$ of $\mathrm{Ag}_{2} \mathrm{O}, \mathrm{ZnO}, \mathrm{CuO}$ and $\mathrm{TiO}_{2}$ powder have been prepared. The sample microstructure was established by FTIR spectroscopy and transmission electron microscopy. The thermal properties, sulfate reducing bacteria and electrical conductivity were investigated. The influence of the inorganic nanoparticles on the thermo stability of poly o-anisidine nanoparticles is very complicated. It was found that POA $/ \mathrm{Ag}_{2} \mathrm{O}$ nanocomposite microspheres have good effects to sulfate reducing bacteria than POA nanoparticle. The value of the electrical conductivity, $\sigma$, of the nanocomposites was investigated. It was found that the poly o-anisidine nanoparticles was improved by adding metal oxides which converted the polymer nanoparticles from insulator behaviour $10^{-16}(\mathrm{~S} / \mathrm{cm})$ to semiconductor behaviour $10^{-11}(\mathrm{~S} / \mathrm{cm})$ in case of $\mathrm{POA} / \mathrm{Ag}_{2} \mathrm{O}$ and $10^{-12}(\mathrm{~S} / \mathrm{cm})$ in case of POA/ZnO. The conductivity was increased by increasing the temperature.
\end{abstract}

Keywords: o-Anisidine; Cationic surfactant; Metal oxide nanoparticles; Sulfur reducing bacteria; Thermal and electrical properties

\section{Introduction}

Among conducting polymers; polyaniline and its derivatives have attracted much attention due to its ease of synthesis; by chemical or electrochemical polymerization; ammonium persulfate is generally used as the oxidizing agent for the preparation. Although the chemical method offers mass production at a reasonable cost; the electrochemical method involves the direct formation of conducting polymer thin films with better control of thickness and morphology; which are suitable for application in electronic devices [1-6]. A novel poly (o-anisidine) (POA)/ $\mathrm{CoFe}_{2} \mathrm{O}_{4}$ nanocomposite was synthesized by a facile in situ polymerization of $\mathrm{o}$-anisidine in the presence of $\mathrm{CoFe}_{2} \mathrm{O}_{4}$ nanoparticles which were obtained by a simple refluxing process in ethylene glycol [7]. However their properties depend on the synthesis conditions such as type of supporting electrolyte; reagent concentration; applied potential; type of solvent and $\mathrm{pH}$ of polymerization bath [8-9]. Polyaniline and its derivatives are mainly used as coating to improve the corrosion resistance of oxidizable metals. These coatings have also been considered for several applications such as the electronic industry; biosensor applications [10-16]. Polyaniline has shown variety of applications such as in rechargeable batteries; electro catalysis; electrochromic displays; gas separation; and biosensors. However; the role of structural and mechanical behaviour of polyaniline and its derivatives for their applications to biosensor has not yet been explored [17].

\section{Scheme of homo polymerization of poly (o-anisidine)}

The incorporation of metal in the form of nanoparticles in the
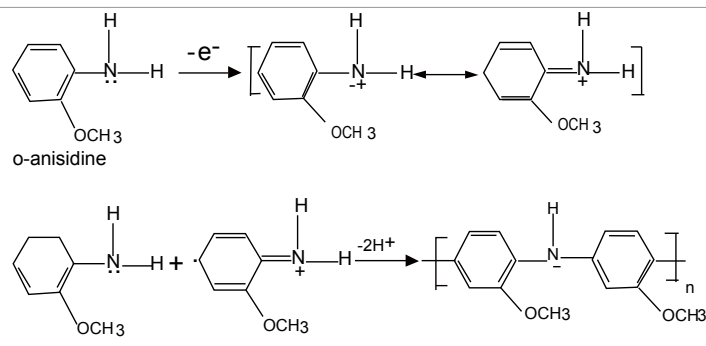

poly (o-anisidine) polymer matrix forms composite materials; which have proved to exhibit improved performances over those of the polymer alone $[18,19]$. Most of the effective corrosion-resistant paint formulations that are popular in industries are based on chromic compounds; which need to be replaced with alternative materials such as polyaniline (PANI) and poly-o-anisidine (POA) [20-23].

Recently; the antibacterial performance of PANI against Escherichia coli and Gram-positive staphylococcus aurous were reported by different research groups [24,25]. Sulphate Reducing Bacteria (SRB) implicated in the deterioration of metals in the oilfield; water recirculation system and marine environments. Mollica and Trevis report that the presence of SRB bio film (sessile) SRB on the metal surface resulted in a higher corrosion rate as compared to the corrosion rate due to plank tonic bacteria alone [26]. In order to control bio corrosion; preventing materials from bio films is a very important method. Currently; the environmental friendly antifouling coating attracts more interest. The present paper described optimized conditions for a successful formation of PNMA microspheres by a simple chemical polymerization method using monomer; acid; and oxidant without any templates. And the resulting PNMA microsphere had good effect to control Sulphate Reducing Bacteria (SRB) and SRB bio films accumulation and then reduced the corrosion rate [27]. In the present work; we report the fabrication of POA nanostructure using cationic surfactant. This study was also focused on the preparation of nanocomposites using different metals oxide nanoparticles .Sulphate Reducing Bacteria (SRB); thermal and electrical properties of the nanostructured $\mathrm{POA} /$ metals oxide nanocomposites were investigated.

*Corresponding author: Azza M.Mazrouaa, Egyptian Petroleum Research Institute, Petrochemical Department, Polymer Lab, Nasr City, Cairo, Egypt, E-mail: azza_mazroua2005@yahoo.com

Received December 20, 2011; Accepted January 23, 2012; Published January 26, 2012

Citation: Mazrouaa AM, Abed MY, Mansour NA, Mohamed MG (2012) Synthesis and Characterization of Poly O-Anisidine Nanoparticles and their Nanocomposite. J Material Sci Eng 1:103. doi:10.4172/2169-0022.1000103

Copyright: (C) 2012 Mazrouaa AM, et al. This is an open-access article distributed under the terms of the Creative Commons Attribution License, which permits unrestricted use, distribution, and reproduction in any medium, provided the original author and source are credited. 


\section{Experimental Procedure}

\section{Materials}

Monomer; O-anisidine; Redox initiator; ammonium persulfate (APS) and -dodecyloxycarbonylmethyl-N-triethanol ammonium chloride as cationic surfactant were purchased from Aldrich (Milwaukee; WI; USA); ( $\mathrm{TiO}_{2}$ nanopowder; average particle size: 25$70 \mathrm{~nm}$; Cat \# 634662; CuO nano powder; average particle size: $450 \mathrm{~nm}$; Cat \# 544868; $\mathrm{Ag}_{2} \mathrm{O}$ powder; Cat \# 221163; $\mathrm{ZnO}$ nano powder; average particle size: $<100 \mathrm{~nm}$; Cat \# 544906; product from Aldrich;).

\section{Synthesis of poly-o-anisidine nanoparticle}

A variable amount of cationic surfactant $\mathrm{N}$-dodecyloxycarbonylmethyl-N-triethanol ammonium chloride [28] was prepared according to Gad et al. [29] was magnetically stirred in $40 \mathrm{ml}$ of distilled water at $3^{\circ} \mathrm{C}$. In a typical fabrication of POA nanoparticles; $1.305 \mathrm{~g}(10.7 \mathrm{~m} \mathrm{~mol})$ of $\mathrm{O}$-anisidine monomers were added dropwise to the surfactant solution and $1.23 \mathrm{~g}(5.3 \mathrm{~m} \mathrm{~mol})$ of APS and $22 \mathrm{~g}(33 \mathrm{~m} \mathrm{~mol})$ of $1.5 \mathrm{M} \mathrm{HCl}$ were added to the mixed solution. The chemical oxidation polymerization proceeded with magnetically stirring for $3 \mathrm{hr}$. After polymerization; the reaction product was placed in a separating funnel. An excess ethanol and distilled water were poured into the funnel alternately to remove the surfactants and to precipitate POA nanoparticles. The POA nanoparticles were retrieved and dried in a vacuum oven at room temperature.

\section{Synthesis of poly-o-anisidine metal nano-oxides}

$1.0 \mathrm{wt} \%$ of polymer nanoparticles prepared from different metal oxide nanopowder was added to $0.2 \mathrm{gm}$. of poly-o-anisidine nanoparticles and stirring until the mixture became homogeneity and the metal oxide nanopowder distributed in the polymer nanoparticles. The polymer-nanocomposites were pressed into pellets $1 \mathrm{~cm}$ diameter and $1 \mathrm{~mm}$ thickness.

\section{Characterization}

\section{Molecular weight}

Molecular weight determination was done by gel permeation chromatography (GPC); The weight average molecular weight was determined by using CRYETTEA instrument- Automatic cryoscope. The method is based on Avogadro-Gerhadt law. The weight average molecular weight; $M_{w}$; was found to be 75457 for poly-o-anisidine nanoparticles.

\section{FTIR spectroscopy}

FT-IR characterizations were performed using a Perkin-Elmer 1650 FTIR spectrophotometer using the $\mathrm{KBr}$ technique.

\section{Transmission electron microscopy (TEM)}

JEOL JEM-1230; $1000 \mathrm{Kv}$ Electron Microscope measured TEM Micrograph of the prepared poly-o-anisidine and for poly-o-anisidine compounds.

\section{Thermogravimetric analysis (TGA)}

The thermal stability of the prepared poly-o-anisidine and for poly-o-anisidine compounds were studied using a thermo gravimetric analyzer. All TGA spectra were recorded under a nitrogen atmosphere up to $600^{\circ} \mathrm{C}$ using a programmed rate of $10^{\circ} \mathrm{C} / \mathrm{min}$.

\section{Antibacterial effect (SRB)}

The antimicrobial activities of the synthesized compounds were evaluated at the Micro Analytical Center (Cairo University) using the modified Kirby-Bauer disc diffusion method [30] against sulfur reducing bacteria (Desulfomonas Pigra); then the activities of the most efficient compounds against SRB strain were further investigated.

\section{Electrical conductivity}

The samples prepared were pressed into pellets of $1.33 \mathrm{~cm}$ diameter and $1 \mathrm{~mm}$ thickness in a hydraulic press (Kimaya Engineers; India; Model WT-324) at five metric ton pressure. The conductivity measurements were carried out by a four-probe technique recorded by a Keithly electrometer type 614. The pellet used in this measurement is placed between two copper electrodes; which were connected to the two terminal of the Keithley electrometer.

\section{Results and discussion}

\section{FTIR spectroscopy}

The spectrum of POA nanoparticles samples table (1) shows that; disappearance of the band $3411 \mathrm{~cm}^{-1}$; new bands at 3646 and 3394 $\mathrm{cm}^{-1}$ appear due to single bridge compounds polymeric association [31]. There is also a band at $3174 \mathrm{~cm}^{-1}$ showing the presence of chelate compounds. The $\mathrm{C}-\mathrm{H}$ stretching vibration is represented by the band $2920 \mathrm{~cm}^{-1}$. The band at $1481 \mathrm{~cm}^{-1}$ may be due to $\mathrm{CH}_{3}$ group or due to aromaticity. Additional bands at 1283; 1199; 1050 and $1004 \mathrm{~cm}^{-1}$ could be assigned to vibrations of the $\mathrm{C}-\mathrm{O}-\mathrm{C}$ bonds of the ether group [32] and aromatic C-O; [33] respectively. Small bands at 608 and $444 \mathrm{~cm}^{-1}$ are due to the presence of $\mathrm{CuO}$ nanopowder; the band at $441 \mathrm{~cm}^{-1}$ is due to $\mathrm{Ag} 2 \mathrm{O}$; the band at $444 \mathrm{~cm}^{-1}$ showing the presence of $\mathrm{ZnO}$ and the bands at 533 and $438 \mathrm{~cm}^{-1}$ are due to $\mathrm{TiO}_{2}$.

\section{TEM analysis}

Figure 1 represents TEM image of the POA nanoparticles. Due to preparation of the polymer nanoparticle in the presence of cationic surfactant (N-dodecyloxycarbonylmethyl-N-triethanol ammonium chloride); POA nanoparticles are shown in the range of nanoscale. Figures 1(a) and (b) of POA nanoparticle pure and $\mathrm{POA} / \mathrm{TiO}_{2}$ nanocomposite; the particle size ranged between 5-7 nm and 35-36 nm in diameter and had spherical shape. But in presence of POA / $\mathrm{Ag}_{2} \mathrm{O}$ nanocomposite ; their sizes varied from 28 to $32 \mathrm{~nm}$ in diameter and appeared as rod shape

(Figure 1c). Figures 1(d) and (e) represented the TEM image of the

\begin{tabular}{|c|c|c|c|c|c|}
\hline \multicolumn{4}{|c|}{ Functional groups } & \multicolumn{2}{|c|}{ IR absorptions $\left(\mathrm{cm}^{-1}\right)$} \\
\hline & $P O A$ & $P O A+C u O$ & $\mathrm{POA}+\mathrm{Ag}_{2} \mathrm{O}$ & $P O A+Z n O$ & $\mathrm{POA}+\mathrm{TiO}_{2}$ \\
\hline \multirow[t]{2}{*}{$\begin{array}{l}\text { Single bridge } \\
\text { compounds }\end{array}$} & 3646 & 3646 & 3646 & 3646 & 3646 \\
\hline & 3394 & 3394 & 3394 & 3394 & 3394 \\
\hline $\begin{array}{l}\mathrm{C}-\mathrm{H} \text { stretching } \\
\text { vibrations }\end{array}$ & 2920 & 2920 & 2920 & 2920 & 2920 \\
\hline $\begin{array}{c}\text { Alkane } \\
\text { monosubstituted } \\
\text { group }\end{array}$ & 2853 & 2853 & 2853 & 2853 & 2853 \\
\hline $\mathrm{C}-\mathrm{O}$ aromatic & 1114 & 1114 & 1114 & 1114 & 1114 \\
\hline $\mathrm{CH}_{3}$ group & 1481 & 1481 & 1481 & 1481 & 1481 \\
\hline \multirow[t]{2}{*}{$\mathrm{C}-\mathrm{O}-\mathrm{C}$ ether } & 1283 & 1283 & 1283 & 1283 & 1283 \\
\hline & 1199 & 1199 & 1199 & 1199 & 1199 \\
\hline $\mathrm{CuO}$ & - & 608 & & & \\
\hline $\mathrm{Ag}_{2} \mathrm{O}$ & - & & 441 & & \\
\hline $\mathrm{ZnO}$ & - & & & 444 & \\
\hline $\mathrm{TiO}$ & - & & & & $533-438$ \\
\hline
\end{tabular}


Citation: Mazrouaa AM, Abed MY, Mansour NA, Mohamed MG (2012) Synthesis and Characterization of Poly O-Anisidine Nanoparticles and their Nanocomposite. J Material Sci Eng 1:103. doi:10.4172/2169-0022.1000103

POA / $\mathrm{CuO}$ nanocomposite; and POA / $\mathrm{ZnO}$ nanocomposite; it seems as cubed shape with 9 to $12 \mathrm{~nm}$ in diameter. It was found that; with different nano metal oxides different shapes and sizes were appeared [34].

\section{Thermogravimetric analysis (TGA)}

Thermogravimetric analysis (TGA) is one of the thermal analysis techniques used to quantify weight change and thermal decomposition of the sample. The TGA curves of pure $\mathrm{TiO}_{2}$ nanoparticles only show a small weight loss; occurring below $400^{\circ} \mathrm{C}$ and can be ascribed to the elimination of water; ethanol and partial dehydroxylation of the $\mathrm{TiO}_{2}$ nanoparticles. The $17.8 \%$ weight loss observed until $347^{\circ} \mathrm{C}$ in the TGA curve of the pure $\mathrm{ZnO}$ nanoparticles is attributed to the elimination of the adsorbed water and to the dehydroxylation process (Figure 2).

In fact; the influence of the inorganic nanoparticles on the thermal stability of POA nanocomposites is very complex; which is related to many factors; such as the synthetic method; type of inorganic nanoparticles; structure of composites; the interaction between two components; and so on [35]. TGA curves of the pure POA nanoparticle and its composites with different metal oxide nanopowder at the same concentration are shown in figure 2 .

The TGA curve of the POA/nano- $\mathrm{ZnO}$ composites also show weight losses between $22.16^{\circ} \mathrm{C}$ and $93.77^{\circ} \mathrm{C}$ attributed to the loss of water from both $\mathrm{ZnO}$ and polymer surfaces; besides a differentiated
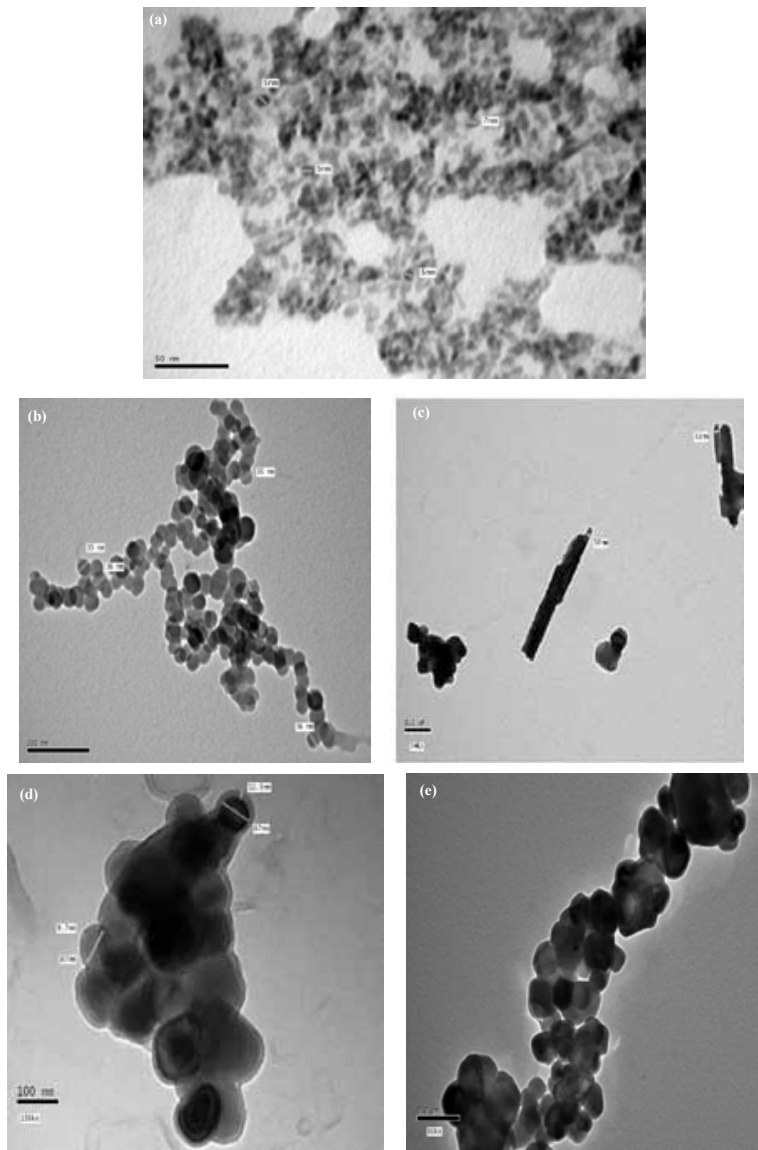

Figure 1: TEM micrograph of (a) POA nanoparticle pure (b) POA nanoparticles $+\mathrm{TiO}_{2}$ (c) POA nanoparticles $+\mathrm{Ag}_{2} \mathrm{O}$ (d) POA nanoparticles+ $\mathrm{CuO}$ (e) POA nanoparticles $+\mathrm{ZnO}$

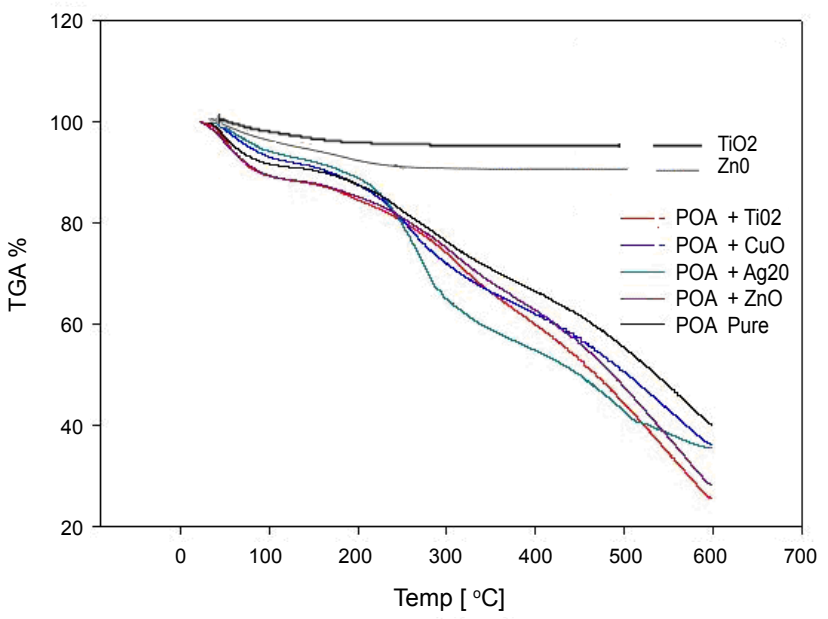

Figure 2: TGA data of $\mathrm{POA} /$ metal oxides powder nanocomposites.

behaviour marked by a strong weight loss in the $94.69-443.45^{\circ} \mathrm{C}$ range. Comparing $\mathrm{POA} /$ nano-composites with $\mathrm{POA}$ pure; it can be seen that the incorporation of $\mathrm{ZnO} ; \mathrm{Ag}_{2} \mathrm{O} ; \mathrm{CuO}$ and $\mathrm{TiO}_{2}$ nanoparticles was lower than that of pure POA. This is the same results of Kumar et al. [36]; who found the decomposition temperature of the PANI nanocomposites with $\mathrm{Cu}_{3} \mathrm{O}_{4}$ nanoparticles was lower than that of pure PANI. But different in the result of Yongjun He [37] who found that $\mathrm{ZnO}$ nanoparticles improves the thermal stability of PANI to a certain extent. However; Kim et al. [38] observed that the thermal stability of PANI was relatively enhanced by forming the nanocomposites with montmorillonite. It seems that the influence of the inorganic nanoparticles on the thermal stability of PANI nanocomposites is very complicated; its mechanism remaining to be addressed.

By comparing the different metal oxides nanopowder; it was found that the weight loss of $\mathrm{POA} / \mathrm{CuO}$ nanocomposite; is $-1.625 \mathrm{mg}$ $(-63.177 \%)$ between $39.38^{\circ} \mathrm{C}$ to $600.06^{\circ} \mathrm{C}$ which is more stable than $\mathrm{POA} / \mathrm{Ag}_{2} \mathrm{O}$ nanocomposite whose weight loss is $-1.410 \mathrm{mg}(-64.453 \%)$ from $38.48^{\circ} \mathrm{C}$ to $600.04^{\circ} \mathrm{C}$ which is more stable than $\mathrm{POA} / \mathrm{ZnO}$ nanocomposite whose weight loss is $-2.090 \mathrm{mg}(-72.096 \%)$ between $22.16^{\circ} \mathrm{C}$ to $600^{\circ} \mathrm{C}$ which is more stable than $\mathrm{POA} / \mathrm{TiO}_{2}$ nanocomposite whose weight loss is $-2.365 \mathrm{mg}(-74.279 \%)$ from $24.06^{\circ} \mathrm{C}$ to $600.01^{\circ} \mathrm{C}$.

\section{Antibacterial effect (SRB)}

It is clear from the data that; the antibacterial activities of the POA/ $\mathrm{Ag}_{2} \mathrm{O}$ nanocomposite microspheres have good effects to sulfate reducing bacteria than POA nanoparticles. It can be used in antibacterial coating in water environment against biocorrosion. As it is shown in table [3a].

\section{Conductivity measurements}

From studying TGA and SRB of polyo-anisidine nanoparticles which prepared by using cationic surfactant $\mathrm{N}$-dodecyloxycarbonylmethyl$\mathrm{N}$-triethanol ammonium chloride; we chosen $\mathrm{Ag}_{2} \mathrm{O}$ and $\mathrm{ZnO}$ as nanopowder to studying the effect of these metal oxides on the electrical conductivity of poly o-anisidine nanoparticles. We can observe that the electrical conductivity of POA nanoparticles pure is in the range of insulator $10-{ }^{16}$; as shown in figure (3); but when added different metal oxides nanopowder; it was found that the electrical conductivity of poly anisidine nanoparticles was improved.

While $\mathrm{Ln} R=2.303 \log \mathrm{R}$ then $\log \mathrm{R}=1 / 2.303 \mathrm{Ln} \mathrm{R}$ 
Citation: Mazrouaa AM, Abed MY, Mansour NA, Mohamed MG (2012) Synthesis and Characterization of Poly O-Anisidine Nanoparticles and their Nanocomposite. J Material Sci Eng 1:103. doi:10.4172/2169-0022.1000103

Page 4 of 5

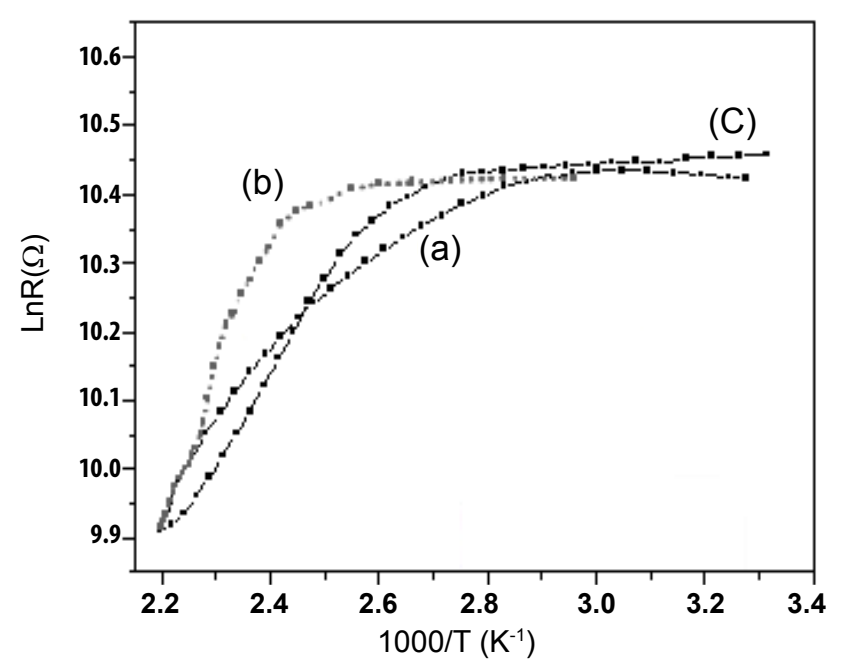

Figure 3: Electrical conductivity of (a) POA nanoparticle pure (b)POA nanoparticles $+\mathrm{Ag}_{2} \mathrm{O}$ (d) POA nanoparticles+ $\mathrm{ZnO}$.

\begin{tabular}{|c|c|c|}
\hline $\begin{array}{l}\text { POA/metal oxides powder } \\
\text { Nanocomposites }\end{array}$ & $\begin{array}{l}\text { Temp. at } 50 \% \text { weight loss } \\
\qquad\left(\mathrm{T}_{50}\right)\left({ }^{\circ} \mathrm{C}\right)\end{array}$ & $\begin{array}{l}\text { weight loss } \% \text { at } \\
6000^{\circ} \mathrm{C}\end{array}$ \\
\hline POA & 440 & $59.543 \%$ \\
\hline POA/ZnO & 500 & $72.096 \%$ \\
\hline $\mathrm{POA} / \mathrm{Ag}_{2} \mathrm{O}$ & 405 & $64.453 \%$ \\
\hline POA/CuO & 515 & $63.177 \%$ \\
\hline $\mathrm{POA} / \mathrm{TiO}_{2}$ & 470 & $74.279 \%$ \\
\hline
\end{tabular}

Table 2: TGA data of POA/metal oxides powder nanocomposites.

\begin{tabular}{|c|c|}
\hline Sample & $\begin{array}{c}\text { Inhibition zone diameter (mm/mg sample) } \\
\text { Tested microorganism: Desulfomonas pigra } \\
\left(\mathrm{G}^{-}\right),(\mathrm{SRB})\end{array}$ \\
\hline $\begin{array}{c}\text { Tetracycline antibacterial } \\
\text { agent (standard) }\end{array}$ & 28 \\
\hline $\mathrm{POA}$ nanoparticle pure & 0.0 \\
\hline $\mathrm{POA} / \mathrm{Ag}_{2} \mathrm{O}$ & 12 \\
\hline $\mathrm{POA} / \mathrm{CuO}$ & 12 \\
\hline $\mathrm{POA} / \mathrm{TiO}_{2}$ & 10 \\
\hline $\mathrm{POA} / \mathrm{ZnO}$ & 10 \\
\hline
\end{tabular}

Table 3 (a): antibacterial activity of POA/metal oxides powder nanocomposites.

\begin{tabular}{|c|c|c|}
\hline Polymer & Conductivity $\boldsymbol{\sigma}$ (S/cm) & Temperature \\
\hline Poly (o-anisidine) & $6.25 \times 10^{-16}$ & $40^{\circ} \mathrm{C}$ \\
\hline Poly (o-anisidine/ $\left./ \mathrm{Ag}_{2} \mathrm{O}\right)$ & $2.50 \times 10^{-14}$ & $120^{\circ} \mathrm{C}$ \\
\hline Poly (o-anisidine/ZnO) & $2.0 \times 10^{-11}$ & $40^{\circ} \mathrm{C}$ \\
\hline
\end{tabular}

Table 3 (b): Different temperature conductivity values of poly (o-anisidine) nanoparticles doped with Different metal oxides

The electrical conductivity $\sigma=1 / \mathrm{R} \Omega^{-1}$; so

$$
\begin{array}{llll}
\text { Ln } \mathrm{R}=2.303 \log \mathrm{R} & \log \mathrm{R}=10^{10.45} / 2.303 & \Omega^{-1} & \text { near } 40^{\circ} \mathrm{C} \text {; and } \\
\text { Ln } \mathrm{R}=2.303 \log \mathrm{R} & \log \mathrm{R}=10^{10.33} / 2.303 \Omega^{-1} & \text { at } 120^{\circ} \mathrm{C} .
\end{array}
$$

When the polymer was mixed with $\mathrm{Ag}_{2} \mathrm{O}$ figure (4-d);

$$
\begin{array}{lll}
\text { Ln } \mathrm{R}=2.303 \log \mathrm{R} & \log \mathrm{R}=10^{10} / 2.303 \Omega^{-1} & \text { near } 40^{\circ} \mathrm{C} \text { and } \\
\mathrm{Ln} \mathrm{R}=2.303 \log \mathrm{R} & \log \mathrm{R}=10^{10} / 2.303 \Omega^{-1} & \text { at } 120^{\circ} \mathrm{C} .
\end{array}
$$

In the case; when the polymer impregnated with $\mathrm{ZnO}$; figure (4-c):

$$
\begin{array}{lll}
\mathrm{Ln} \mathrm{R}=2.303 \log \mathrm{R} & \log \mathrm{R}=10^{11} / 2.303 \Omega^{-1} & \text { near } 40^{\circ} \mathrm{C} \text {; and } \\
\mathrm{Ln} \mathrm{R}=2.303 \log \mathrm{R} & \log \mathrm{R}=10^{10} / 2.303 \Omega^{-1} & \text { at } 120^{\circ} \mathrm{C} .
\end{array}
$$

It was found that the resistance of the polymer nanoparticles decreases with increase of temperature. Also the electrical conductivity of the polymer nanoparticle increases when the polymer was impregnated with metal oxide nanopowder. The increase in electrical conductivity differs with the metal oxide used. Accordingly; it's shown that poly (o-anisidine $\left./ \mathrm{Ag}_{2} \mathrm{O}\right)$ the highest electrical conductivity than poly (o-anisidine/ $\mathrm{ZnO}$ ). Table $3 \mathrm{~b}$ show the effect of temperature on the electrical conductivity. This means that by adding metal oxides poly o-anisidine nanoparticles converted from insulator behaviour to semiconductor behaviour which can uses in electronic industry.

\section{Conclusion}

The following conclusions have been drawn from the present study. A poly-o-anisidine nanoparticles was prepared in presence of cationic surfactant $\mathrm{N}$-dodecyloxycarbonylmethyl-N-triethanol ammonium chloride. FTIR spectra of pure POA nanoparticles and POA nanoparticles in presence of $\mathrm{CuO} ; \mathrm{ZnO} ; \mathrm{TiO}_{2}$ and $\mathrm{Ag}_{2} \mathrm{O}$ were determined. The transmission electron microscopy (TEM) and Thermogravimetric analysis (TGA) were studied. From TGA; it was found that the influence of the inorganic nanoparticles on the thermal stability of poly o-anisidine nanoparticles is very complicated. The antimicrobial activities of the synthesized compounds were evaluated; it was found that the $\mathrm{POA} / \mathrm{Ag}_{2} \mathrm{O}$ nanocomposite microspheres have good effects on the sulfate reducing bacteria than POA nanoparticles. The electrical measurements declare that the poly o-anisidine nanoparticles was improved by adding metal oxides which converted the polymer nanoparticles from insulator behaviour $10^{-16}(\mathrm{~S} / \mathrm{cm})$ to semiconductor behaviour $10^{-11}(\mathrm{~S} / \mathrm{cm})$ in case of $\mathrm{POA} / \mathrm{Ag}_{2} \mathrm{O}$ and 10 ${ }^{12}(\mathrm{~S} / \mathrm{cm})$ in case of $\mathrm{POA} / \mathrm{ZnO}$. Also the conductivity was increased by increasing the temperature.

\section{References}

1. Borole DD, Kapadi UR, Mahulikar PP, Hundiwale DG (2006) J Mater Sci 41 1983-1990.

2. Camatel JL, Lacroix JC, Aciyach S, Chaneching K, Lacaze PC(1998) Synth Met 93: 133 .

3. Yang CH, Wen TC (1994) J Appl Electrochem 24:166.

4. Liao DC, Hsich KH, Chern YC, Ho K S (1997) Synth Met 87: 61.

5. Roth S, Graupner W (1993) ibid 57: 3623.

6. Bartlett PN, Birkin PR (1993) Anal Chem 65: 1118.

7. Jing Jiang, Lun-Hong Ai, Ai-Hua Liu (2010) Synthetic materials 160: 333-336.

8. Kupila EL, Kankare J (1993) ibid 55: 1402.

9. Stankovie R, Pavlovic O, Vojnovic M, Jovanovic S (1994) Eur Polym J 30: 385

10. Ozyilmaz AT, Ozyilmaz G, Imaz EY, Çolak N (2008) Korean J Chem Eng 25: 846-853.

11. Fenelon AM, Breslin CB (2005) Surf Coat Tech 190: 264.

12. Rajendran V, Gopalan A, Vasudevan T, Chen WC, Wen TC (2000) Mat Chem Phys 65: 320.

13. Martyak NM, McAndrew P, McCaskie JE, Dijon (2002) Prog Org Coat 45: 23. 14. Shinde V, Sainkar SR, Patil PP (2005) J Appl Polym Sci 96: 685.

15. Kilmartin P A, Trier L, Wright GA (2002) Synth Met 131: 99.

16. Eftekhari A (2004) Synth Met 145: 211.

17. Savale PA, Shirsat MD (2009) Appl Biochem Biotechnol 159: 299-309.

18. Mallick K, Witcomb MJ, Scurrell MS (2006) Sci JM 41: 6189-6192. 
Citation: Mazrouaa AM, Abed MY, Mansour NA, Mohamed MG (2012) Synthesis and Characterization of Poly O-Anisidine Nanoparticles and their Nanocomposite. J Material Sci Eng 1:103. doi:10.4172/2169-0022.1000103

Page 5 of 5

19. Gangopadhyay R, De A (2000) Chem Mater 12: 608

20. Jadhav RS, Hundiwale DG, Mahulikar PP (2009) J Coat Technol Res Published online 16.

21. Alam J, Riaz U, Ashraf SM, Ahmad S (2008) Corrosion- Protective Performance of Nano Polyaniline/Ferrite Dispersed Alkyd Coatings. J Coat Technol Res 5: 123-128.

22. Laco JII, Villota FC, Metres FL (2005) Prog Org Coat 52: 151-160.

23. Armelin E, Oliver R, Liesa F, Iribarren JI, Estrany F, et al.(2007) Prog Org Coat 59: $46-52$

24. Shi N, Guo X, Jiang H (2006) J Mater Sci Technol 22: 289-290.

25. Seshadri DT, Bhat NV (2005) J Fibre \&Textile Res 30: 207-210

26. Molica A, Trevis AA (1977) S Acciaio Inossidabile 44: 3-13

27. Hongfang LIU, Huang L, Huang Z, Gongtai QI, KEI Sanada, et al. (2008) Journal of Wuhan University of Technology-Mater Sci Ed 536-540.

28. Jang J, Ha J, Kim S (2007) Macromolecular Research 15: 154-159.
29. Gad EAM, Abdel-Hamid Z, Ismail DA, and El-Adly RA (1999) J Chem Technol Biotechonl 74: 345-348.

30. Bauer AW, Kirby WM, Sherris C,Turck M (1966) American Journals of clinica pathology 45:493 (1966).

31. John R Dyer (1971) Application of Absorption Spectroscopy of Organic Compounds prentice-Hall of India 36.

32. Pecsok RL, Shields LD, Cairns T, McWilliam IG (1976) Modern Methods of Chemical Analysis, 2nd ed. Wiley, New York.

33. Silverstein RM, Bassler GC (1968) Spectrometric Identification of Organic Compounds, 2nd ed. Wiley, New York.

34. Fawzia I El-Dib, Wafaa M Sayed Sahar. M. Ahmed, Mohamed Elkodary (2011) J Appl Polym Sci, accepted and published in 2011.

35. SU Bitao, MIN Shixiong, SHE Shixiong, TONG Yongchun, BAI Jie (2007) Front Chem China 2: 123-126.

36. Kumar V, Mastai Y, Gedanken A (2000) Chem Mater 12: 3892.

37. Yongjun He (2004) Powder Technology 147: 59-63

38. Kim B, Jae J, Seung H, Jinsoo J (2002) Macromolecules 35: 1419 